abnormalities. Infections included frequent, recurrent upper and lower respiratory tract infections (otitis media in $46 \%$ patients, sinusitis in $27 \%$, bronchitis in $19 \%$, and pneumonia in $15 \%$ ). Uncomplicated varicella infection occurred in $44 \%$ of patients. Systemic bacterial, severe viral, and opportunistic infections are uncommon in A-T, and the immune defect is rarely progressive. (Nowak-Wegrzyn, Crawford TO, Winkelstein JA et al. Immunodeficiency and infections in ataxia-telangiectasia. J Pediatr April 2004;144:505511). (Reprints: Howard M Lederman MD, PhD, Division of Pediatric Allergy and Immunology, The Johns Hopkins Hospital, CMSC 1102, 600 N Wolfe St, Baltimore, MD 21287).

COMMENT. Despite significant immune system abnormalities, patients with A-T are not commonly subject to systemic bacterial, severe viral, and opportunistic infections. The progressive neurodegenerative process typical of A-T is not accompanied by a worsening immune defect with age. A-T, a neurocutaneous syndrome, results from a defect in DNA repair. The A-T gene (known as ATM, for AT 'mutated') has been mapped to chromosome 11 (11q22.3) (Charrow J. Neurocutaneous syndromes. In: Millichap JG, ed. Progress in Pediatric Neurology III, PNB Publishers;435-439).

\title{
RASMUSSEN ENCEPHALITIS WITH DELAYED SEIZURE ONSET
}

Two children, ages 6 and 7 years, with progressive hemiparesis and radiological and histopathological confirmation of Rasmussen encephalitis (RE) had no seizures or epileptic EEG activity until 6 to 7 months after onset of symptoms, in a report from Bikur Cholim Hospital, Jerusalem, Israel. The onset of epilepsy with RE may be dissociated from the early inflammatory stage of the disease. (Korn-Lubetzki I, Bien CG, Bauer J et al. Rasmussen encephalitis with active inflammation and delayed seizure onset. Neurology March (2 of 2) 2004;62:984-986). (Dr I Korn-Lubetzki, Neurological Service, Bikur Cholim Hospital, Strauss St 5, PO Box 492, Jerusalem 91004, Israel).

COMMENT. Seizures as a presenting symptom are not a sine qua non for a diagnosis of Rasmussen encephalitis, but partial seizures, often epilepsia partialis continua, following a nonspecific febrile illness are the usual early manifestations of the syndrome. Seizures are usually accompanied by a progressive hemiparesis, hemianopia, and aphasia and MRI evidence of a contralateral hemicerebral atrophy. RE is thought to be an immune mediated disorder, and immunological abnormalities include elevated antinuclear antibodies, especially autoantibodies to the glutamate receptor subunit 3 (GluR3), CSF oligoclonal bands, elevated immunoglobulins, and cytotoxic T cells in brain tissue specimens.

Bed rest following lumbar puncture was studied at the Pediatric Hospital, University of Heidelberg, Germany, in 111 patients aged 2 to 17 years. Significantly more head or backaches were encountered in the group kept at 24-hour strict bed rest than in patients allowed free mobility (headaches 39 vs $21 \%$; backaches 42 vs $23 \%$, respectively). Prophylactic bed rest following lumbar puncture in children and adolescents is of no benefit and may increase the risk of headache or backache. (Ebinger F et al. Neurology March ( 2 of 2) 2004;62:1003-1005). 